\title{
49. SYNTHESIS OF STRATIGRAPHIES FROM SHALLOW-WATER SEQUENCES AT SITES 871 THROUGH 879 IN THE WESTERN PACIFIC OCEAN ${ }^{1}$
}

\author{
Elisabetta Erba, ${ }^{2}$ Isabella Premoli Silva, ${ }^{2}$ Paul A. Wilson, ${ }^{3}$ Malcolm S. Pringle,${ }^{4}$ William V. Sliter,${ }^{5}$ \\ David K. Watkins, ${ }^{6}$ Annie Arnaud Vanneau, ${ }^{7}$ Timothy J. Bralower, ${ }^{8}$ Ann F. Budd, ${ }^{9}$ \\ Gilbert F. Camoin, ${ }^{10}$ Jean-Pierre Masse, ${ }^{10}$ Jörg Mutterlose, ${ }^{11}$ and William W. Sager ${ }^{12}$
}

\begin{abstract}
This paper discusses the synthesis of bio-, magneto-, and isotope stratigraphies in the shallow-water sediment sequences drilled on guyots in the western Pacific Ocean during Leg 144. Material previously dredged from the slopes of a few guyots and the Cretaceous section recovered at Site 869 are also considered. The integrated stratigraphy along with radiometric ages resulted in the reconstruction of the geological events that produced atolls and guyots.
\end{abstract}

\section{INTRODUCTION}

During Ocean Drilling Program (ODP) Leg 144, five guyots were drilled in the western Pacific Ocean (see site map preceding title page). Main objectives included the study of the formation of the volcanic edifices, the development and demise of carbonate platforms, and the subsequent deposition of pelagic sediments over the drowned platforms. Drilling results indicate that volcanic episodes were followed by carbonate platform deposition in the late Paleocene-Eocene (Site 871, Limalok Guyot), Campanian-Maastrichtian (Sites 873 through 877, Wodejebato Guyot), and Aptian-Albian (Site 878, MIT Guyot, and Site 879, Takuyo-Daisan Guyot) (Premoli Silva, Haggerty, Rack, et al., 1993; Shipboard Scientific Party, 1993). Although the morphology of Lo-En Guyot is the typical morphology of a guyot, no shallowwater sequences were recovered at Site 872, where pelagic sedimentation immediately followed the formation of a volcanic edifice.

The deposition of the Cretaceous and Paleogene carbonate platforms ended with the formation of hardgrounds, phosphatized horizons, and manganese crusts and nodules that record a complex sedimentary history. The drowning of the carbonate platforms was followed by pelagic sedimentation strongly affected by currents that winnowed the summit of the guyots. Therefore, the Tertiary and Quaternary pelagic sections at the five guyots are characterized by sporadic accumulation and intervals of nondeposition and/or erosion.

${ }^{1}$ Haggerty, J.A., Premoli Silva, I., Rack, F., and McNutt, M.K. (Eds.), 1995. Proc. $O D P$, Sci. Results, 144: College Station, TX (Ocean Drilling Program).

${ }^{2}$ Dipartimento di Scienze della Terra, Università di Milano, Via L. Mangiagalli 34. I-20133 Milano, Italy.

${ }^{3}$ Department of Earth Sciences, University of Cambridge, Downing Street, Cambridge CB2 3EQ, United Kingdom.

${ }^{4}$ Center for Isotope Geology, Faculty of Earth Sciences, Free University, De Boelelaan 1085, 1081 HV Amsterdam. The Netherlands. (Present address: Scottish Research and Reactor Centre, East Kilbride, Glasgow G75 0QU, Scotland.)

${ }^{3}$ Paleontology and Stratigraphy Branch, U.S. Geological Survey, 345 Middlefield Road, Menlo Park, CA 94025, U.S.A.

${ }^{6}$ Department of Geology, University of Nebraska, 330 Bessey Hall, Lincoln, NE 68588-0340, U.S.A.

${ }^{7}$ Institut Dolomieu, Université de Grenoble, rue Maurice Gignoux, F-30031 Grenoble Cedex, France.

${ }^{8}$ Department of Geology, University of North Carolina, CB 3315 Mitchell Hall, Chapel Hill, NC 27599-3315, U.S.A.

${ }^{9}$ Department of Geology, The University of lowa, 121 Trowbridge Hall, lowa City, IA 52242-1379, U.S.A

${ }^{10}$ Centre de Sédimentologie et Paléontologie, U.R.A. 1208 du C.N.R.S., Université de Provence, 3 place Victor Hugo, F-13331 Marseille Cedex 3, France.

${ }^{11}$ Institut für Geologie, Ruhr-Universităt Bochum, Universitätstrasse 150, Postfach 102148. D-44801 Bochum, Federal Republic of Germany.

${ }^{12}$ Department of Oceanography, Texas A\&M University, College Station, TX 77843 . 3146, U.S.A.
A key point for the geological reconstruction of the western $\mathrm{Pa}$ cific Ocean guyots is a high-resolution stratigraphy of the sedimentary sequences and precise absolute ages of volcanic rocks. Although the stratigraphies of the sedimentary sections and the radiometric ages of the volcanic rocks recovered during Leg 144 are documented in a number of papers included in this volume, we synthesize here the stratigraphic results from the shallow-water sequences. A detailed reconstruction of the sedimentary history preserved in the manganese crusts is provided by Watkins et al. (this volume); in this paper, we will consider only the age of the oldest pelagic sediment marking the platform drowning. The geological synthesis of the pelagic cap sediments is discussed in a separate chapter of this volume (Watkins et al., this volume). The absolute ages provided by Pringle and Duncan (this volume) are discussed here to reconstruct the timing and the sequence of the various events. Also, the stratigraphic results from Site 869 drilled during ODP Leg 143 on the archipelagic apron south of Wodejebato Guyot are included in this paper. Comparison with the shallow-water sequences drilled on the summit of Wodejebato Guyot (Sites 873 through 877 ) will result in a more exhaustive reconstruction of the area.

The stratigraphic framework reported in the Frontispiece was adopted as Leg 144 reference for the Barremian to Maastrichtian interval. Based on recent papers (Van Gorsel, 1978; Schroeder and Neumann, 1985; Jones, 1992; McArthur et al., 1992, 1993; Krijnen et al., 1993; Neumann, 1993; Cecca et al., 1994; Erba, 1994; McArthur, 1994; Premoli Silva and Sliter, 1994; Coccioni and Premoli Silva, 1994; Arnaud Vanneau and Premoli Silva, this volume; Erba et al., this volume; Premoli Silva et al., this volume; Watkins et al., this volume; Wilson et al., this volume), calcareous nannofossil and planktonic and benthic foraminifer biostratigraphies as well as $\mathrm{Sr}$-isotope stratigraphy are correlated with magnetic polarity chrons and calibrated with the time scale recently proposed by Gradstein et al. (1994).

The five guyots are presented here site by site with a discussion of the stratigraphic resolution and the resulting stratigraphic framework.

\section{LIMALOK GUYOT (SITE 871)}

Three holes were drilled at Site 871 in $1255 \mathrm{~m}$ water depth in the south central portion of Limalok Guyot, southern Marshall Islands. Holes $871 \mathrm{~A}$ and $871 \mathrm{~B}$ were cored to 151.9 and $152.4 \mathrm{mbsf}$, respectively; we were able to recover the pelagic cap atop the carbonate platform and the contact between the pelagic cap and the shallowwater limestone. Hole $871 \mathrm{C}$ was washed through the pelagic cap and cores were recovered from 133.7 to $500 \mathrm{mbsf}$. The recovered section consists of shallow-water limestone (133.7-422.9 mbsf), clay (422.9-451.5 mbsf), and basalt (451.5-500 mbsf). 
An integrated stratigraphy for Hole $871 \mathrm{C}$ is presented in Figure 1. The lower part of the section is represented by $48.5 \mathrm{~m}$ of interbedded volcanogenic sandstones and basaltic breccias and flows (Unit IV). Material suitable for radiometric dating was not recovered at this site; therefore, the age of the volcanic pedestal can only be inferred from the biostratigraphic age of the oldest sediment. Volcanics are followed by $29 \mathrm{~m}$ of variegated clays with common basalt pebbles in the lower part (Unit III and uppermost part of Unit IV). This interval was identified by Holmes (this volume) as a subaerial weathering profile over the basalt. The thickness of this interval attests to a long period of exposure, probably beginning in an upland area at least several tens of meters above sea level. According to Holmes (this volume), such a weathering profile required no less than $1 \mathrm{~m} . \mathrm{y}$. of soil formation and most probably as much as 3 m.y.

The oldest marine sediment consists of dark gray aragonitic grainstones and clays (base of Subunit IIF), which contain depauperate nannofloras of early late Paleocene age (Premoli Silva, Haggerty, Rack, et al., 1993; Watkins et al., this volume). The initial stage of inundation of the island occurred under relatively restricted conditions and was followed by a thick sequence $(289.2 \mathrm{~m})$ of shallowwater limestones (Subunits IIF through IIA). The biostratigraphy of the carbonate platform sequence is based on benthic foraminifers (Nicora et al., this volume) and indicates that the shallow-water limestones began to accumulate in the latest Paleocene and persisted through the early Eocene into the early middle Eocene. Major hiatuses were not detected (Nicora et al., this volume). Sr-isotope measurements were performed by Wilson et al. (this volume) and Wyatt et al. (this volume), and the resulting curves indicate a general early Paleogene age for the carbonate platform.

The youngest platform carbonates on Limalok Guyot were dated as early middle Eocene (Nicora et al., this volume), and the oldest pelagic sediment was found in the manganese-phosphatic crust atop the shallow-water sequence. Pelagic limestone entrapped within the crust yielded a well-diversified nannofossil assemblage indicative of the Zone CP13 and planktonic foraminifers of Zone P14 (Watkins et al., this volume). This planktonic assemblage tightly constrains the date of the platform demise to middle Eocene. Therefore, the carbonate platform drowned and open-marine conditions were established over the guyot by middle Eocene time (Premoli Silva, Haggerty, Rack, et al., 1993; Watkins et al., this volume).

\section{LO-EN GUYOT (SITE 872)}

Three holes were drilled at Site 872 on the central part of Lo-En Guyot in the northern Marshall Islands (see site map preceding title page). The position of Site 872 is in the thickest part of the pelagic cap on the guyot; in fact, one of the major drilling objectives was the recovery of a possibly complete pelagic section. The pelagic cap, the contact with the underlying limestone/chalk-basalt pebble conglomerate, and the topmost basalts were recovered in Holes $872 \mathrm{~A}$ and $872 \mathrm{C}$, which were cored to a depth of $144 \mathrm{mbsf}$. Hole $872 \mathrm{~B}$ was washed to $77 \mathrm{mbsf}$, and three cores were recovered in the interval from 77.3 to 106.3 mbsf. Hole $872 \mathrm{~B}$ was washed again to $135.2 \mathrm{mbsf}$, at which point coring again resumed to 192.5 mbsf. The three upper cores contain part of the pelagic cap, whereas the lower section (from 135.2 to $192.5 \mathrm{mbsf}$ ) consists of limestone/limestone-basalt pebble conglomerate and the underlying basalts with pelagic limestone filling the fractures in the uppermost $60 \mathrm{~cm}$.

Figure 2 reports the stratigraphic information and the radiometric dates of Hole $872 \mathrm{~B}$, in which the oldest portion of the geological history of the guyot was recovered. Although Lo-En Guyot is morphologically a classic guyot, drilling did not recover any platform sequence and persistent pelagic sedimentation was observed immediately above the volcanic pedestal. Pringle and Duncan (this volume) provided radiometric ages for two rock samples from the alkalic basalts (Unit IV). The sample from Core 144-872B-9R gave an age of $113.3 \pm 1.4 \mathrm{Ma}$ (Fig. 2), and the sample from Core 144-872C-18X was dated as $111.3 \pm 2.4 \mathrm{Ma}$. The weighted isochron age is $112.8 \pm$ 1.2 Ma (Fig. 2). Because the standard used by Pringle and Duncan (this volume) is different from that used by Obradovich (1993), the ages provided by Pringle and Duncan (this volume) for volcanic rocks cannot be directly compared to the time scale used as a reference (Gradstein et al., 1994) and reported in the frontispiece. Applying the conversion factor to the ages reported by Pringle and Duncan (this volume), the volcanic pedestal on Lo-En Guyot yields an age of 114 . $5 \pm 1.2 \mathrm{Ma}$, which falls in the Aptian of the geologic time scale.

Only a few fragments of black claystones atop vesicular basalts in Hole $872 \mathrm{C}$ indicate a possible derivation from a relatively fresh to moderately weathered terrane (Holmes, this volume). The oldest sediment is a phosphatized clast of pelagic limestone in a pebble conglomerate (Unit III) (Sample 144-872B-4R-1, 13-16 cm); it contains a depauperate nannoflora of Albian to earliest Cenomanian age (Watkins et al., this volume). Pelagic sediments also occur as crack fillings (Unit IV) and as the matrix of the volcaniclastic pebble conglomerate lying atop the basaltic pedestal (Units II and III) (Premoli Silva, Haggerty, Rack, et al., 1993; Watkins et al., this volume). The intense phosphatization and the small sizes of the samples limit the biostratigraphic resolution. However, a few samples from the sediments infilling cracks in the basalts contained planktonic foraminifers of the $D$. concavata Zone to the base of the $D$. asymetrica Zone and calcareous nannofossils indicative of the $\mathrm{CC} 12-\mathrm{CC} 15$ and $\mathrm{CC} 15$ Zones and suggest a Coniacian to early Santonian age (Premoli Silva, Haggerty, Rack, et al., 1993; Erba et al., this volume; Watkins et al., this volume).

In the lower samples within Core 144-872B-4R, planktonic foraminifer assemblages resemble the assemblages from the Coniacian to lower Santonian, but seem to display an older character caused by reworking or preservation. Increase in phosphatization resulting in poor preservation of tests could also explain the older aspect of the microfauna. However, the occurrence of Albian to earliest Cenomanian calcareous nannofossils (Watkins et al., this volume) favors the hypothesis of reworking of older planktonic foraminifers. This interpretation is further supported by the presence of middle neritic benthic foraminifers in the late Coniacian-Santonian limestones, which suggests transport of shallow-water debris into a deeper site of deposition. Conversely, the benthic assemblage may indicate deposition in a shallow pelagic environment (Premoli Silva, Haggerty, Rack, et al., 1993). Two species of benthic foraminifers associated with calcareous plankton are Dictyopselloides sp. (Samples 144-872B-4R-1, 46$48,60-62$, and $68-71 \mathrm{~cm}$ ) and Dorothia sp. cf. D. bulletta (Sample $144-872 \mathrm{~B}-4 \mathrm{R}-1,68-71 \mathrm{~cm})$. The latter species is known from the Upper Cretaceous, whereas the genus Dictyopselloides is known from the Santonian of France and Spain. Their occurrence is consistent with the age inferred from the calcareous plankton.

The results of dredges along the southern slope of Lo-En Guyot (Lincoln et al., 1993) are consistent with the depositional history derived from material recovered at Site 872, and add important and complementary information. Dredge RD33 recovered a breccia of angular fragments of basalts floating in a matrix of shallow-water debris and pelagic carbonates with planktonic foraminifers. The shallow-water debris was dated as Albian, and the oldest pelagic sediment was attributed to the latest Albian. Younger pelagic material in the breccia was dated as Coniacian and early Campanian on the basis of the planktonic foraminifers present in the dredge haul (Lincoln et al., 1993). The Albian carbonate platform postdated the late Aptian volcanic edifice on Lo-En Guyot, and the latest Albian to Campanian pelagic sediments are correlative to those recovered at Site 872 .

\section{WODEJEBATO GUYOT (SITES 873 THROUGH 877 AND SITE 869)}

Five sites were drilled on Wodejebato Guyot in the northern Marshall Islands: Site 873 was drilled in the central part of the guyot, Sites 874 and 877 were located on the inner ridge of the northeastern margin, and Sites 875 and 876 were drilled on the outer ridge of the 


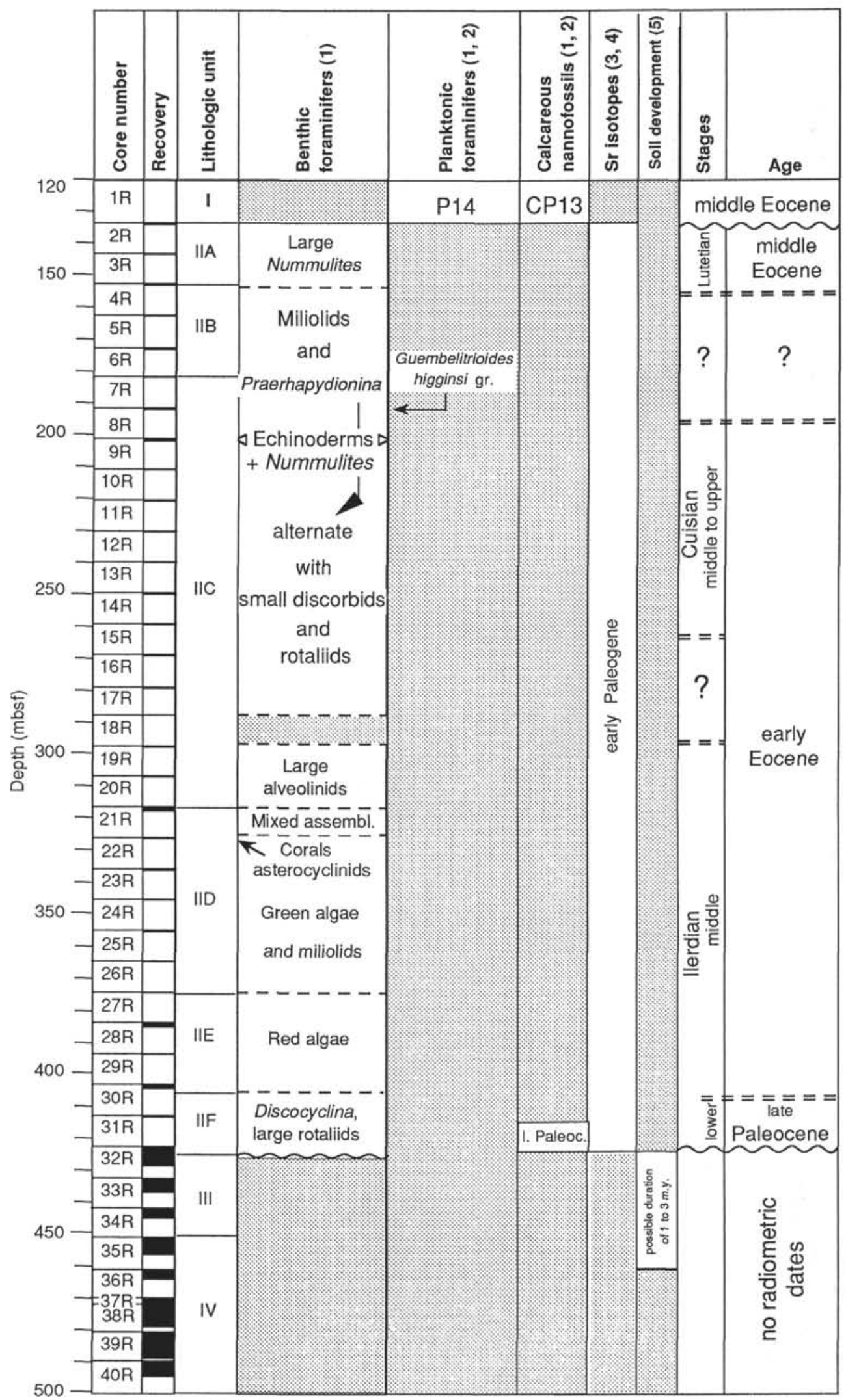

Figure 1. Stratigraphic synthesis of Hole $871 \mathrm{C}$ on Limalok Guyot. Gray pattern corresponds to the interval with no data. References are as follows: (1) Nicora et al. (this volume); (2) Watkins et al. (this volume); (3) Wilson et al. (this volume); (4) Wyatt et al. (this volume); and (5) Holmes (this volume). 


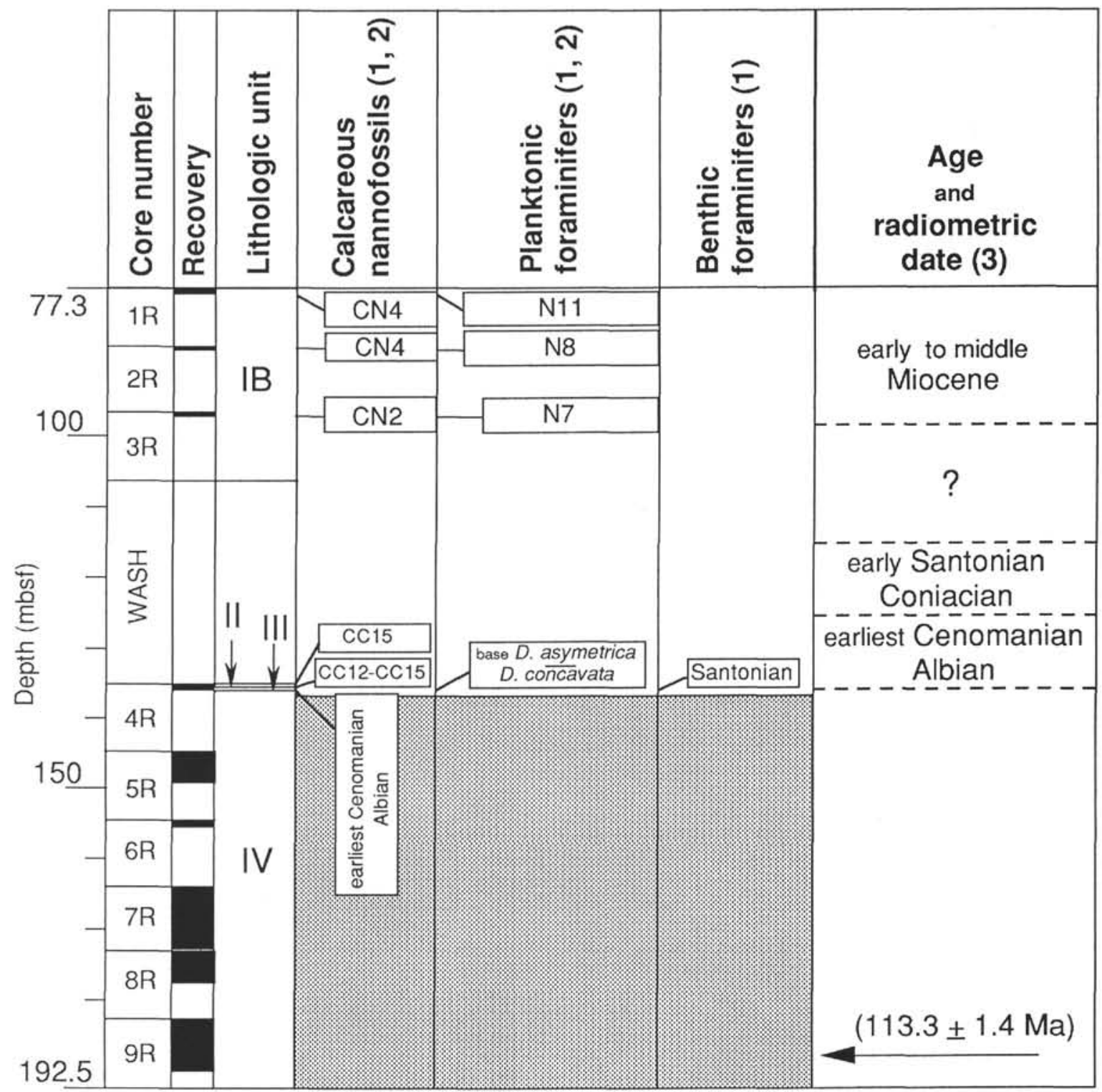

Figure 2. Stratigraphic synthesis of Hole 872B on Lo-En Guyot. Gray pattern corresponds to the interval with no data. Mean weighted age (Cores 144-872B-9R and 144-872C-18X) $=112.8 \pm 1.2 \mathrm{Ma}(3)=114.4 \pm 1.2 \mathrm{Ma}$. References are as follows: (1) Erba et al. (this volume); (2) Watkins et al. (this volume); and (3) Pringle and Duncan (this volume).

northeastern margin. Stratigraphies and the radiometric ages are discussed site by site.

\section{Site 873 (Lagoon)}

Two holes were drilled at Site 873. After washing through the pelagic cap, Hole $873 \mathrm{~A}$ was cored from 54.3 to $252.3 \mathrm{mbsf}$. The material recovered at this hole includes a manganese crust and a manganese-phosphatized limestone conglomerate from 54.3 to 59.8 mbsf; shallow-water limestones from 69.3 to 151.5 ; ferruginous clay and claystone from 151.5 to $175.1 \mathrm{mbsf}$; altered basalt from 175.1 to 204.3 mbsf, and volcanic breccia from 204.3 to $232.2 \mathrm{mbsf}$. Hole $873 \mathrm{~B}$ recovered the pelagic cap $(0-58 \mathrm{mbsf})$ and the contact with the underlying carbonate platform from 58 to 69 mbsf.

Figure 3 reports the stratigraphic synthesis for Hole 873A, whereas Hole $873 \mathrm{~B}$ is discussed in detailed by Watkins et al. (this volume). Pringle and Duncan (this volume) provided radiometric dates of two hawaiites from Cores 144-873A-17R and -18R (Fig. 3). Averaging all the dates available for Wodejebato Guyot, the weighted mean age of the volcanic substrate is $83.2 \pm 1.1 \mathrm{Ma}$ (Pringle and Duncan, this volume), which, using the conversion factor, results in an age of $84.4 \pm$ 1.1 Ma. Paleomagnetic measurements by Nakanishi and Gee (this volume) and Ito and Nogi (this volume) indicate that the basalts are reversely magnetized and are attributed to Chron 33R of early Campanian age.

At Site 873 , the 22.5 -m-thick clayey interval atop the basalts (Cores 144-873A-12R and -13R) was interpreted as the result of soil development. This weathering profile exhibits an extreme alteration and pedogenesis and might have formed in an upland or lowland area (Holmes, this volume). The oldest marine sediment consists of black clays that contain well-preserved, late Campanian calcareous nannofloras at the top of lithologic Unit IV. The flooding of the volcanic edifice occurred under restricted conditions and was followed by the establishment of a Campanian to Maastrichtian carbonate platform (Subunits IIIB and IIIA). The biostratigraphy of the shallow-water limestones is based on benthic foraminifers (Premoli Silva et al., this volume). The abundant and diverse assemblages suggest a late Campanian to Maastrichtian age, but it is impossible to locate the Cam- 


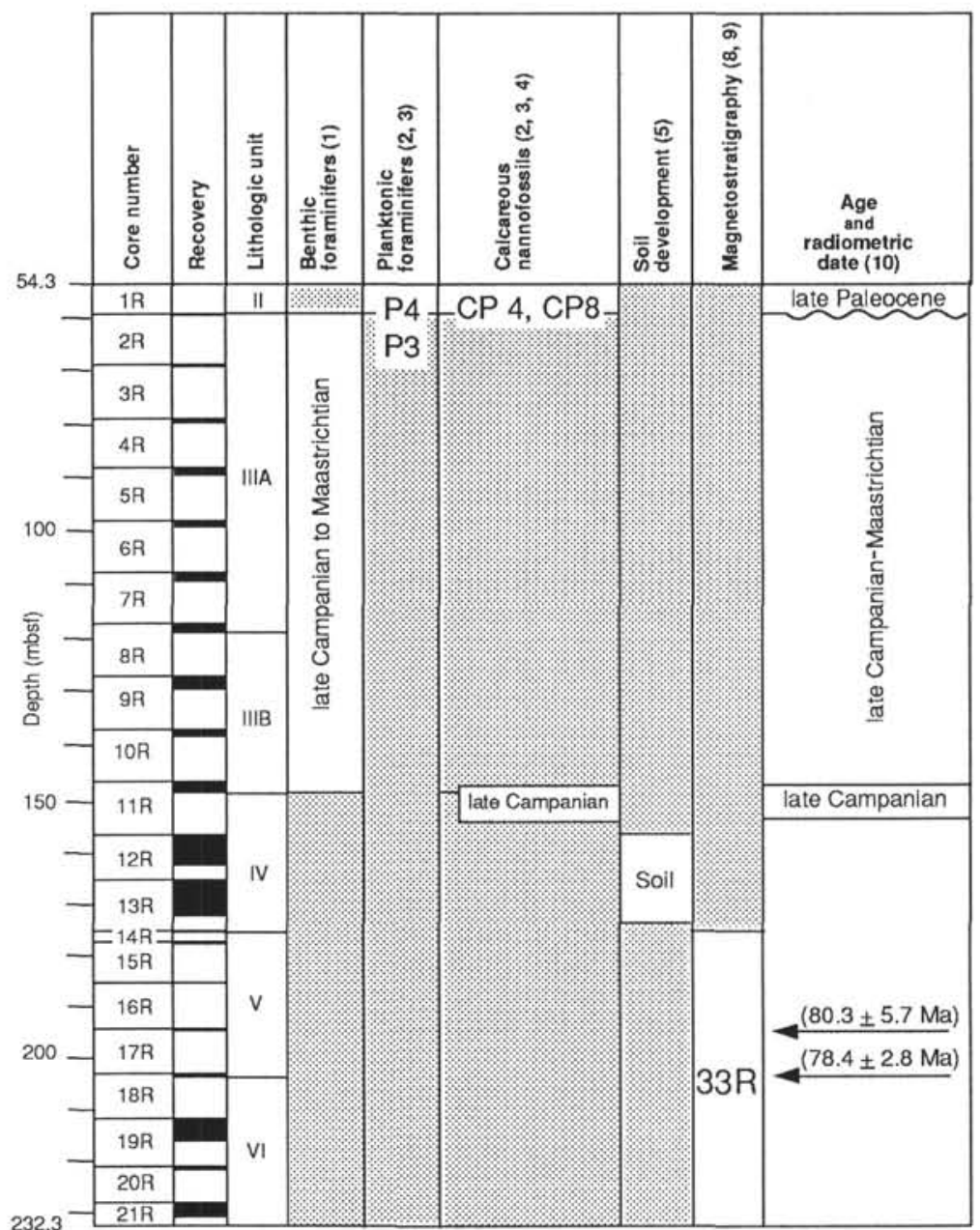

Figure 3. Stratigraphic synthesis of Hole 873A in the central part of Wodejebato Guyot. Gray pattern corresponds to interval with no data. Mean weighted age for basalts drilled on Wodejebato Guyot $($ Sites 873,874 , and 876$)=83.2 \pm 1.1 \mathrm{Ma}(10)=84.4 \pm$ 1.1 Ma. References are as follows: (1) Premoli Silva et al. (this volume); (2) Watkins et al. (this volume); (3) Erba et al. (this volume); (4) Erba et al. (this volume); (5) Holmes (this volume); (6) Wilson et al. (this volume); (7) Wyatt et al. (this volume); (8) Nakanishi and Gee (this volume); (9) Ito and Nogi (this volume); (10) Pringle and Duncan (this volume); and (11) Camoin et al. (this volume).
panian/Maastrichtian boundary precisely. No material from this hole was suitable for $\mathrm{Sr}$-isotope stratigraphy.

The oldest pelagic sediment is entrapped within the manganese crust that characterizes the top of the carbonate platform. Calcareous nannofossils attributable to Zones CP4 and CP8 and planktonic foraminifers of Zones P3 and P4 indicate that in late Paleocene time the platform at this site was under pelagic conditions.

\section{Sites 874 and 877 (Inner Ridge)}

In an attempt to acquire reefal limestones, Sites 874 and 877 were drilled on the inner ridge along the northeastern rim of Wodejebato Guyot. Two holes (874A and 874B) were drilled at Site 874, and a single hole was drilled at Site 877 (Hole 877). Only one core was drilled at Hole 874A, whereas Hole 874B was cored to 193.5 mbsf. The material recovered at the latter hole includes a manganese crust (0-0.11 mbsf), a carbonate platform sequence (0.11-162.82 mbsf), ferruginous clay and claystone (162.82-177.7 mbsf), and a single flow of altered basalt (177.7-193.5 mbsf). The radiometric age of $85.0 \pm 1.5 \mathrm{Ma}$ (uncorrected value) is derived from an ankaramite sample in Core 144-874B-24R (Pringle and Duncan, this volume) (Fig. 4). The volcanics are reversely magnetized and are assigned to magnetic polarity Chron 33R (Nakanishi and Gee, this volume).

Lithologic Unit III (Cores 144-874B-22R and -21R), on top of the volcanic substrate, displays a weathering profile that is less distinctive than at Site 873 (Holmes, this volume). The initial flooding at this site is dated as late Campanian on the basis of well-preserved, albeit rare calcareous nannofossils in Core 144-874B-21R (Erba et al., this volume). Marine sedimentation continued with the deposition of shallow- water limestones (Unit II) capped by a hardground (Unit I). Benthic foraminifers provide the biostratigraphic control for the carbonate platform (Premoli Silva et al,, this volume), with a minor contribution by rudists (Camoin et al., this volume). Only a general late Campanian to Maastrichtian age is derived by biostratigraphy; again, it is impossible to fix accurately the location of the Campanian/Maastrichtian boundary. Sr-isotope stratigraphy (Wyatt et al., this volume) indicates that Maastrichtian values occur from the top of the carbonate platform to $145 \mathrm{mbsf}$, whereas Campanian values were measured for the bottom part of the sequence. Therefore, we locate the Campanian/Maastrichtian boundary at $145 \mathrm{mbsf}$; this assignment is compatible with the planktonic and benthic organism biostratigraphy. The oldest pelagic sediments were found in a cavity at the top of the carbonate platform. They contain planktonic foraminifers of late Maastrichtian age and document the drowning of Wodejebato before the end of the Cretaceous. In the manganese crust enclosing the shallow-water limestones, planktonic foraminifer assemblages attributable to Zones $\mathrm{P} 4$ and $\mathrm{P} 7 / 8$ indicate a late Paleogene and early Eocene age, respectively. The oldest pelagic sediment dated by calcareous nannofossils was found in the manganese crust. The assemblage is suggestive of Zone CP10 of early Eocene age (Watkins et al., this volume).

The section recovered at Site 877 is very similar in lithology and age to that recovered from Hole $874 \mathrm{~B}$ (Fig. 4). No radiometric dates are available for the volcanic substrate (Unit IV), which is assigned to magnetic polarity Chron 33R (Nakanishi and Gee, this volume). Similar to Hole $874 \mathrm{~B}$, a weathering profile was recognized atop the basalt (Unit III) (Holmes, this volume). The base of the marine sequence is marked by black clays (base of Subunit IIE) that contain age-diagnostic calcareous nannofossils (Erba et al., this volume). A well-preserved 
Hole 877A

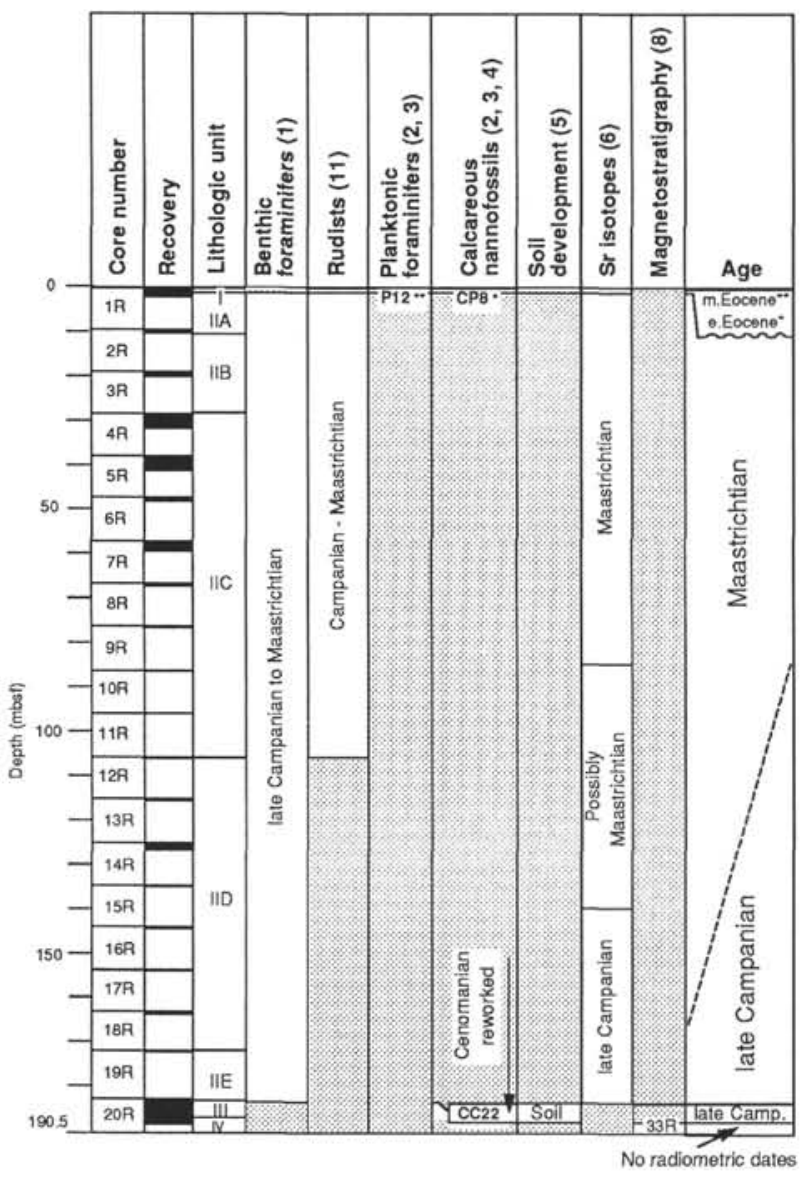

Holes $874 \mathrm{~A}$ and $874 \mathrm{~B}$

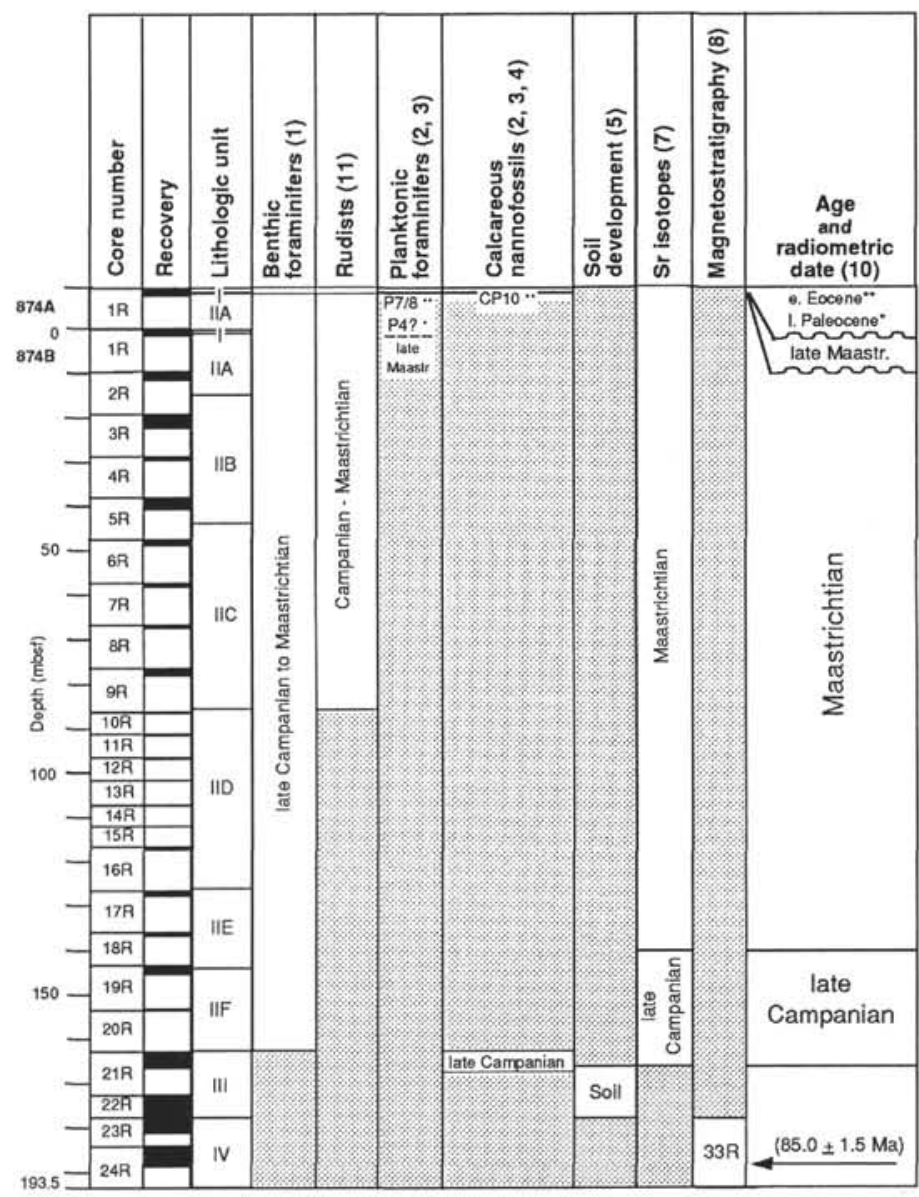

Figure 4. Stratigraphic synthesis of Holes 874A, 874B, and 877A on the inner ridge of Wodejebato Guyot. Gray pattern corresponds to interval with no data. References as listed in Figure 3. Asterisks identify the age of calcareous nannofossil $(* *)$ and planktonic foraminifer $(*)$ zones.

nannoflora of Zone $\mathrm{CC} 22$ constrains the onset of marine conditions to the late Campanian. At this level, Cenomanian-restricted nannofossils document the presence on Wodejebato Guyot of older pelagic carbonates that were resedimented during the late Campanian. This late Campanian sedimentation occurred under restricted conditions and was followed by the establishment of a Campanian to Maastrichtian carbonate platform. The biostratigraphy of the shallow-water sequence is primarily based on benthic foraminifers (Premoli Silva et al., this volume), with a minor contribution by rudists (Camoin et al., this volume). Similar to Hole 874B, Sr- isotope data (Wilson et al., this volume) provided constraints to place the Campanian/Maastrichtian boundary. In fact, Maastrichtian values were found down to $85 \mathrm{mbsf}$ and possibly down to $154 \mathrm{mbsf}$. The lower portion of the carbonate platform (Cores 144-877A-16R to -19R) gave Campanian $\mathrm{Sr}$-isotope values.

The drowning of the carbonate platform is documented in the manganese crust atop the shallow-water limestones. Here, calcareous nannofossils of Zone CP8 date the onset of pelagic conditions as early Eocene. The oldest planktonic foraminifers at Site 877 are middle Eocene in age (Zone P12) (Watkins et al., this volume) (Fig. 4).

\section{Sites 875 and 876 (Outer Ridge)}

Sites 875 and 876 were drilled on the outer ridge along the northeastern rim of Wodejebato Guyot. Three holes were drilled at Site 875, and one hole was drilled at Site 876 . Only $36 \mathrm{~cm}$ of poorly cemented, coarse skeletal sands were recovered at Hole $875 \mathrm{~A}$. The same lithology was recovered at Hole $875 \mathrm{~B}$, which was abandoned after drilling $40 \mathrm{~m}$ (four cores) because of poor hole conditions. Hole $875 \mathrm{C}$ penetrated $133 \mathrm{~m}$ of section and recovered a manganese crust on top of 125.86 $\mathrm{m}$ of shallow-water limestones and $7 \mathrm{~m}$ of basalts. A very similar section was recovered at Site $876: 8 \mathrm{~cm}$ of manganese crust, $145 \mathrm{~m}$ of shallow-water limestones, and $8.6 \mathrm{~m}$ of volcanics. No pelagic caps were recovered at Sites 875 and 876 . Stratigraphies and radiometric ages from Holes $875 \mathrm{C}$ and $876 \mathrm{~A}$ are illustrated in Figure 5.

Although no absolute ages are available for the volcanics at the base of Hole $875 \mathrm{C}$, two radiometric dates were obtained from Core 144-876A-17R: $73.0 \pm 3.6$ and $82.8 \pm 2.2 \mathrm{Ma}$, respectively (Pringle and Duncan, this volume) (Fig. 5). The volcanics at both sites are assigned to magnetic polarity Chron $33 \mathrm{R}$ of early Campanian age (Nakanishi and Gee, this volume). No weathering profiles were recovered on the outer ridge, where marine sedimentation is represented by shallow-water limestones immediately overlying the volcanics. The clayey interval found at Sites 873,874 , and 877 was not recovered at Sites 875 and 876.

The carbonate platform sequences at Sites 875 and 876 were dated using benthic foraminifer biostratigraphy. Assemblages clearly indicate that these sequences are younger than the sequences at Site 873 (lagoon) and 874 and 877 (inner ridge) and are Maastrichtian in age (Premoli Silva et al., this volume).

The youngest shallow-water carbonates at both Sites 875 and 876 are late Maastrichtian in age and are only slightly older than the late Maastrichtian drowning of Wodejebato Guyot, as documented by planktonic foraminifers in pelagic limestones infilling the top of the platform at Site 874 (Premoli Silva, Haggerty, Rack, et al., 1993; 
Hole 876A

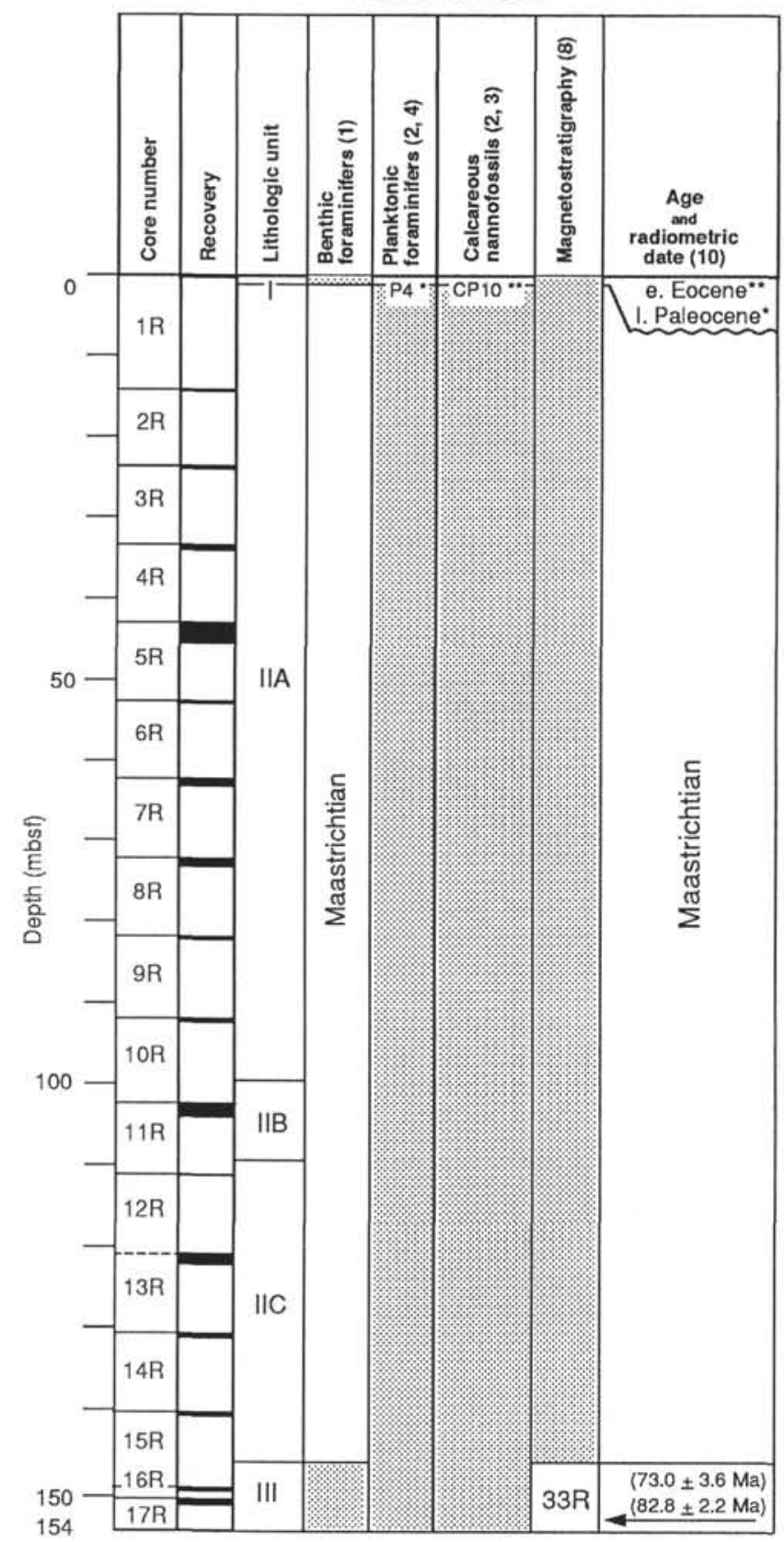

Hole $875 \mathrm{C}$

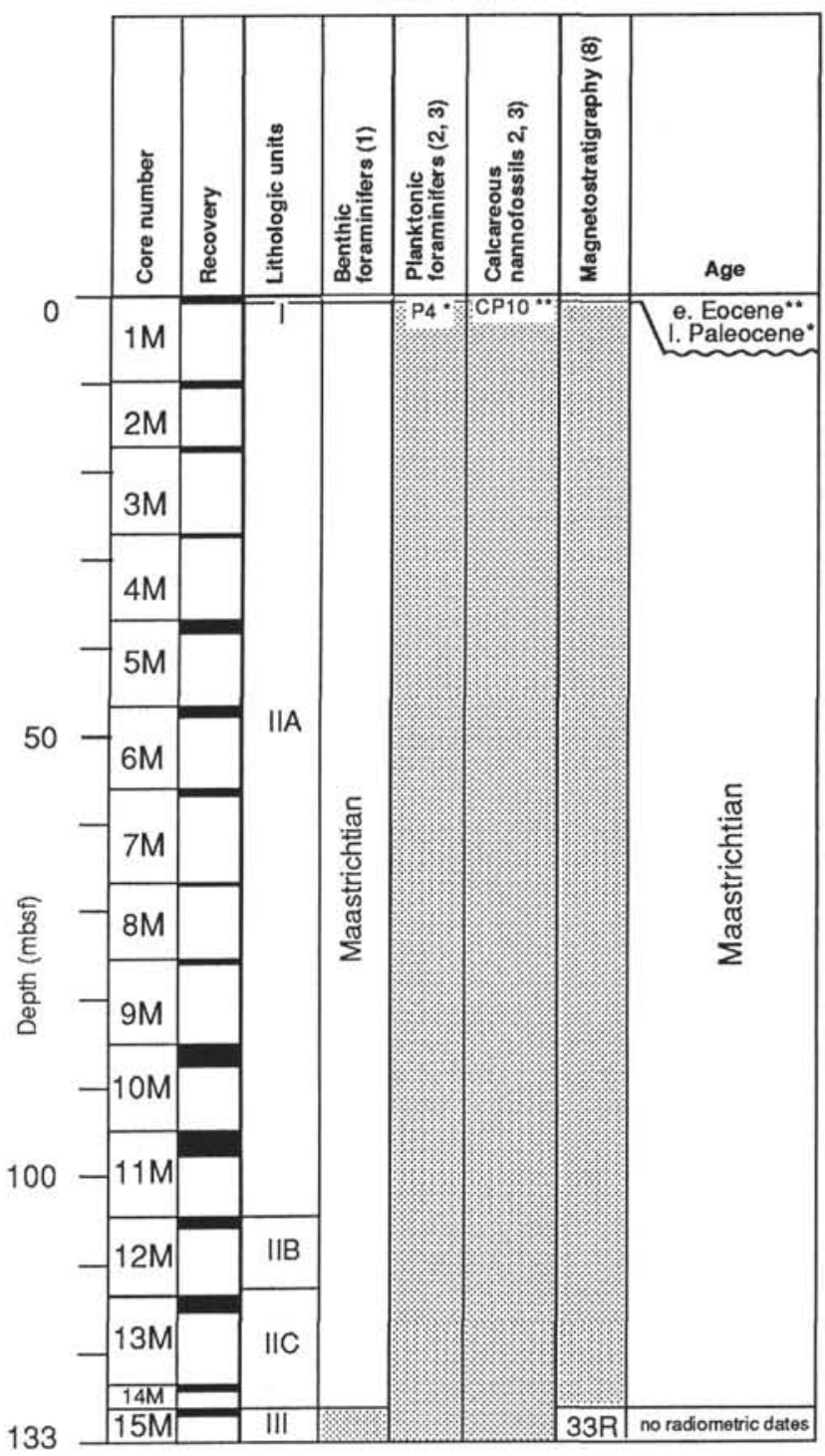

Figure 5. Stratigraphic synthesis of Holes $875 \mathrm{C}$ and $876 \mathrm{~A}$ on the outer ridge of Wodejebato Guyot. Gray pattern corresponds to interval with no data. References as listed in Figure 3. Asterisks identify the age of calcareous nannofossil (**) and planktonic foraminifer (*) zones.

Watkins et al., this volume). Pelagic sediments are preserved in the hardground developed on the top of the carbonate platform at Sites 875 and 876 . At both locations, the oldest planktonic foraminifer assemblages indicate Zone P4 of late Paleocene age, whereas Zone $\mathrm{CP} 10$ of early Eocene age is the oldest nannofossil occurrence on the outer ridge (Watkins et al., this volume) (Fig. 5).

\section{Site 869 (Archipelagic Apron South of Wodejebato Guyot)}

Site 869 was drilled during Leg 143 on the archipelagic apron south of Wodejebato Guyot to recover a basinal reference section for comparison to Leg 144 sites on the summit of the guyot (Sager, Winterer, Firth, et al., 1993). Two holes were drilled at this site. Hole
869A was drilled in $4837.8 \mathrm{~m}$ water depth; it penetrated $88.2 \mathrm{~m}$ of nannofossil ooze and $78.3 \mathrm{~m}$ radiolarian-nannofossil ooze with porcellanite and chert. Hole $869 \mathrm{~B}$ ( $4837.8 \mathrm{~m}$ water depth) was washed to $140 \mathrm{mbsf}$ and was cored continuously to $796.2 \mathrm{mbsf}$. The recovered section consists of $77.2 \mathrm{~m}$ of radiolarian-nannofossil ooze and nannofossil-radiolarian ooze with porcellanite and chert (Unit II), and 579 $\mathrm{m}$ of volcaniclastics interlayered with nannofossil and radiolarian claystone (Unit III) (Sager, Winterer, Firth, et al., 1993).

The stratigraphic synthesis of the Cretaceous sequence drilled at Hole 869B is reported in Figure 6. Most of this Upper Cretaceous sequence consists of volcaniclastic breccias and sandstones mixed with pelagic sediments, with two major volcanic pulses (Subunits IIIA2 and IIID, respectively). Biostratigraphic ages are based on integrated calcareous nannofossil (Sager, Winterer, Firth, et al., 1993; 
Erba et al., this volume) and planktonic foraminifer (Sliter, 1995) events. Nannofloras from Zones CC9 to CC23 were identified and indicate a Cenomanian to Campanian age. In the same interval (Cores 143-969B-10R to -57R), planktonic foraminifers occur with poor preservation and varying abundance (Sliter, 1995).

Shallow-water debris was recovered in the thick volcaniclastic sequence at Site 869 (Fig. 6), where it is mostly resedimented at the base of the turbidites. The documentation of this debris is based on shipboard descriptions (Sager, Winterer, Firth, et al., 1993), which was further incremented by shore-based investigation (W.V. Sliter and I. Premoli Silva, unpubl. data, 1994). Coalified woody fragments were found in Core 143-869B-51R, indicating the presence of a forested island in the area. Within the Cenomanian section, reworked material was also observed in Cores 143-869B-50R, -49R, -44R, and $-36 \mathrm{R}$. The shallow-water debris consists of rare benthic foraminifers, gastropods, and rare bryozoans, but no age-diagnostic forms were recovered. Another pulse of resedimented material is preserved in the lowermost Turonian (Cores 143-869B-35R and -34R) by layers of abundant but poorly preserved ooids and pellets. A single specimen of a possible cuneolinid may provide age information (W.V. Sliter and I. Premoli Silva, unpubl. data, 1994) and is under investigation.

Resedimentation of shallow-water debris ceased during the Coniacian-Santonian; only one layer was observed in Core 143869B-32R. The Campanian documents a rejuvenation of resedimentation as represented by shallow-water debris at various levels from Cores 143-869B-26R to -10R (Fig. 6). The benthic foraminifer assemblages are very similar to those recovered at the sites drilled on the summit of Wodejebato Guyot. In particular, numerous Pseudorbitoides and rare specimens tentatively attributed to Sulcoperculina and Vaughanina were observed in Cores 143-869B-11R and -10R (W.V. Sliter and I. Premoli Silva, unpubl. data, 1994).

Four samples from the Cenomanian volcaniclastic breccia at Site 869 were dated by Pringle and Duncan (this volume). The resulting weighted age is $94.4 \pm 0.3 \mathrm{Ma}$, which yields a converted age of $95.7 \pm$ $0.3 \mathrm{Ma}$ for the Cenomanian episode (Fig. 6). The absolute age and the nannofossil biostratigraphic age of the Cenomanian volcanics at the apron site are consistent with the reworked nannofossils found at Site 877 on the Inner Ridge of Wodejebato Guyot (Erba et al., this volume).

The Campanian volcanic episode is well dated by the calcareous nannofossil and planktonic foraminifer biostratigraphy and by magnetostratigraphy. Cores 143-869B-26R through -21R were identified as magnetic polarity Chron $33 \mathrm{R}$ of early Campanian age (Sager, Winterer, Firth, et al., 1993; Sager et al., 1995) (Fig. 6). Hence, the volcaniclastics at Site 869 are correlative of the volcanic substrate drilled at Sites 873 through 877 on the summit of Wodejebato Guyot.

\section{Other Data from Previous Studies}

Dredges from the southern slope of Wodejebato Guyot recovered material that is discussed by Lincoln et al. (1993). Dredge RD47 contained a breccia consisting of basalt pebbles and a calcareous matrix with planktonic foraminifers of late Santonian to early Campanian age. Manganese-encrusted limestone and shallow-water debris were recovered with Dredge RD50. Two generations of shallowwater material were identified: the younger was attributed to the Campanian-Maastrichtian based on the benthic foraminifers, and the older is dated as Albian based on the rudists. The latter age assignment was revised to a possible Cenomanian age after the conclusion of Legs 143 and 144 (see the notes added in proofs in Lincoln et al., 1993). However, the biostratigraphic resolution of the recovered rudists does not allow discrimination between Albian and Cenomanian.

The dredged material and the drilling results suggest that Wodejebato experienced at least two episodes of volcanism and the subsequent building of a carbonate platform. Although evidence exists for a Campanian-Maastrichtian carbonate platform on Wodejebato, no shallow-water organisms of certain Cenomanian through Campanian age have been recorded in the area.

\section{MIT GUYOT (SITE 878)}

Site 878 is located in $1323 \mathrm{~m}$ water depth on the northeastern part, just inside the southern perimeter ridge of MIT Guyot. Three holes were drilled at this site. Hole $878 \mathrm{~A}$ was a multiple reentry hole, whereas Holes $878 \mathrm{~B}$ and $878 \mathrm{C}$ were single-core holes, specifically drilled to recover the pelagic cap and the contact with the carbonate platform. We summarize here the stratigraphic results and absolute ages from Hole $878 \mathrm{~A}$. The material recovered includes the pelagic cap with manganese nodules ( 0 - $3.2 \mathrm{mbsf}$ ), shallow-water limestone (3.2-339.7 mbsf), breccia with basalt and limestone clasts (399.5-604 mbsf), shallowwater carbonates (604-722.5 mbsf), and basalt (722.5-910 mbsf).

The integrated stratigraphy of Hole $878 \mathrm{~A}$ is presented in Figure 7 along with radiometric ages. Radiometric dating of the basalts allowed the identification of three analytically distinct groups of ages (Pringle and Duncan, this volume). The lower basalt samples averaged 123. $1 \pm 0.6 \mathrm{Ma}$; one basanite (Core 144-878A-80R) yielded an age of $121.7 \pm 0.7 \mathrm{Ma}$; and three hawaiites, one from the upper lava sequence and two from clasts found near the top of the polymictic breccia, provided an age of $119.6 \pm 0.7 \mathrm{Ma}$ (Pringle and Duncan, this volume). Using the conversion factor for Pringle and Duncan's data, the age of the volcanic pedestal ranges from 124.5 to $121.3 \mathrm{Ma}$. The bottom $60 \mathrm{~m}$ of basalts are reversely magnetized (Nakanishi and Gee, this volume; Ito and Nogi, this volume) and were identified as Chron M1r (Erba et al., this volume; Pringle and Duncan, this volume). Atop the volcanics, $9 \mathrm{~m}$ of clays may represent the very deep parts of a soil profile or alteration by groundwaters (Holmes, this volume).

Shallow-water deposition produced a very thick sequence of limestones interrupted by the breccia of lithologic Unit IV. Biostratigraphy of the carbonate platforms and the polymictic breccia primarily relies on benthic foraminifers (Arnaud Vanneau and Premoli Silva, this volume), with additional information derived from the calcareous algae (Masse and Arnaud Vanneau, this volume) and corals (A.F. Budd in Premoli Silva et al., this volume). Based on benthic foraminifers, the lower carbonate platform sequence (Unit V) is attributed to the early Aptian, and all the shallow-water limestone clasts recovered within the breccia contain benthic foraminifers of early late Aptian age. The lowermost part of the upper carbonate platform sequence (Unit III) is late Aptian to early Albian in age; the middle Albian was identified by benthic foraminifers in Cores 144-878A-38M through $-25 \mathrm{M}$. From Core 144-878 A-24M upward, benthic foraminifers indicate a late Albian age (Fig. 7).

Calcareous algae occur sporadically in the shallow-water carbonates at Site 878 (Masse and Arnaud Vanneau, this volume). Although only a general Barremian to Albian age is derived for the lowermost findings, all the specimens recovered from Cores 144-878A-68R through $-45 \mathrm{M}$ indicate an early Aptian age. This age assignment of the material in the breccia suggests resedimentation of older material during the early late Aptian, as defined by the benthic foraminifers (Fig. 7). Calcareous algae from the upper carbonate platform (Units III and II) are Albian in age.

A few specimens of corals found at Site 878 are not age diagnostic, but paleoecologic implications are discussed by Premoli Silva et al. (this volume). Sr-isotope measurements were conducted on selected samples through the sequence recovered at Site 878 . The wide-spaced sampling does not allow a high-resolution stratigraphy, and only a late Aptian to late Albian age can be derived. However, Sr-isotope values from Core 144-878A-1R suggest that the top of the carbonate platform was deposited in the latest Albian (Wilson et al., this volume).

Calcareous nannofossils and planktonic foraminifers occur only in a few layers within the mid-Cretaceous shallow-water sequence at Site 878 (Erba et al., this volume). Calcareous nannofossils in Core 144878A-75R indicate the Chiastozygus litterarius Zone of early Aptian age. Moreover, the relative dominance of nannoconids allows precise correlation to the lower portion of the zone, which is the interval including the reversed polarity Chron M0 immediately preceding the "nannoconid crisis" (Erba, 1994). Calcareous nannofossils apparently 


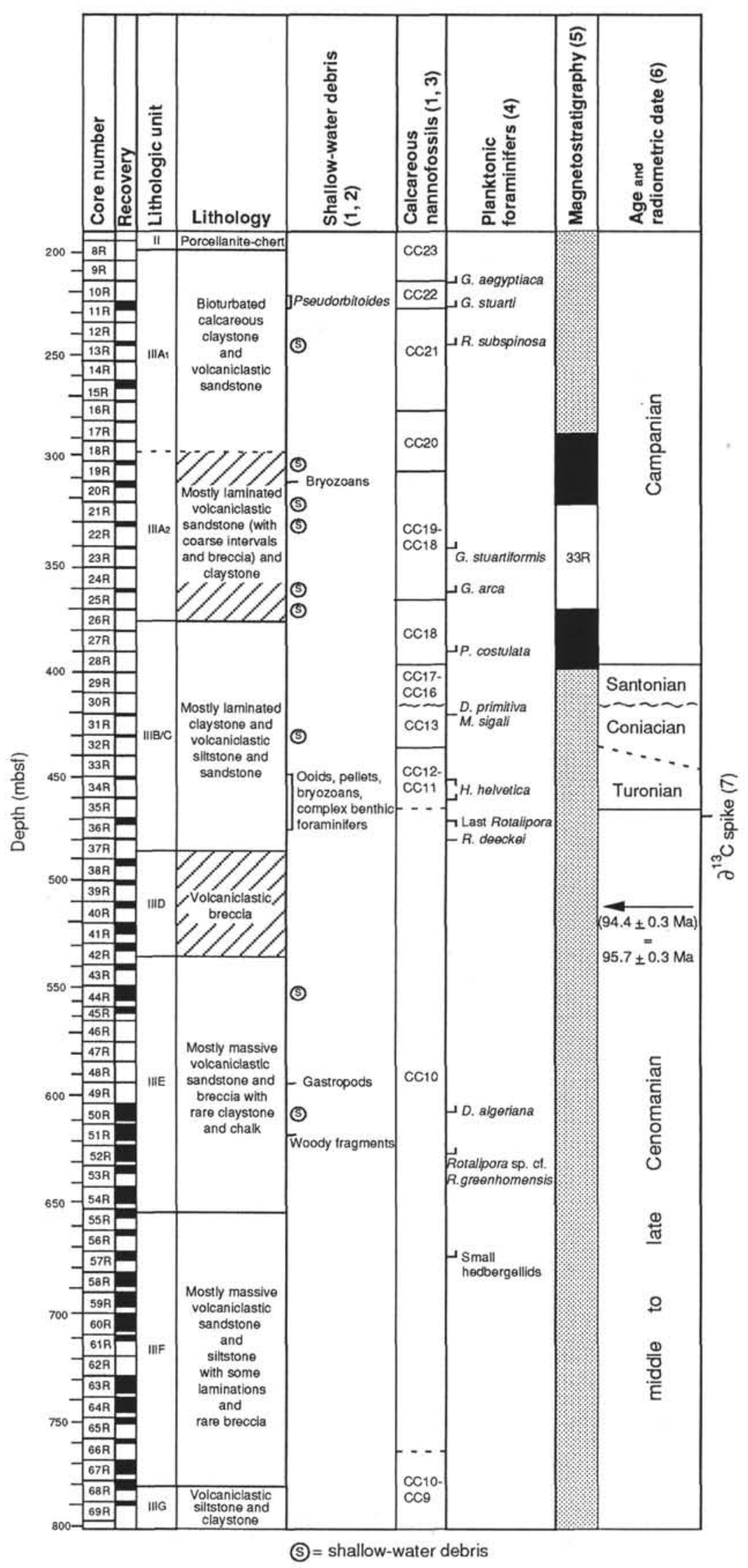

Figure 6. Stratigraphic synthesis of the Cretaceous section at Hole 869B. Gray pattern corresponds to interval with no data. References are as follows: (1) Sager, Winterer, Firth, et al. (1993); (2) W.V. Sliter and I. Premoli Silva (unpubl. data, 1994); (3) Erba et al. (this volume); (4) Sliter (1995); (5) Sager et al. (1995); (6) Pringle and Duncan (this volume); and (7) Jenkyns et al. (1995). 

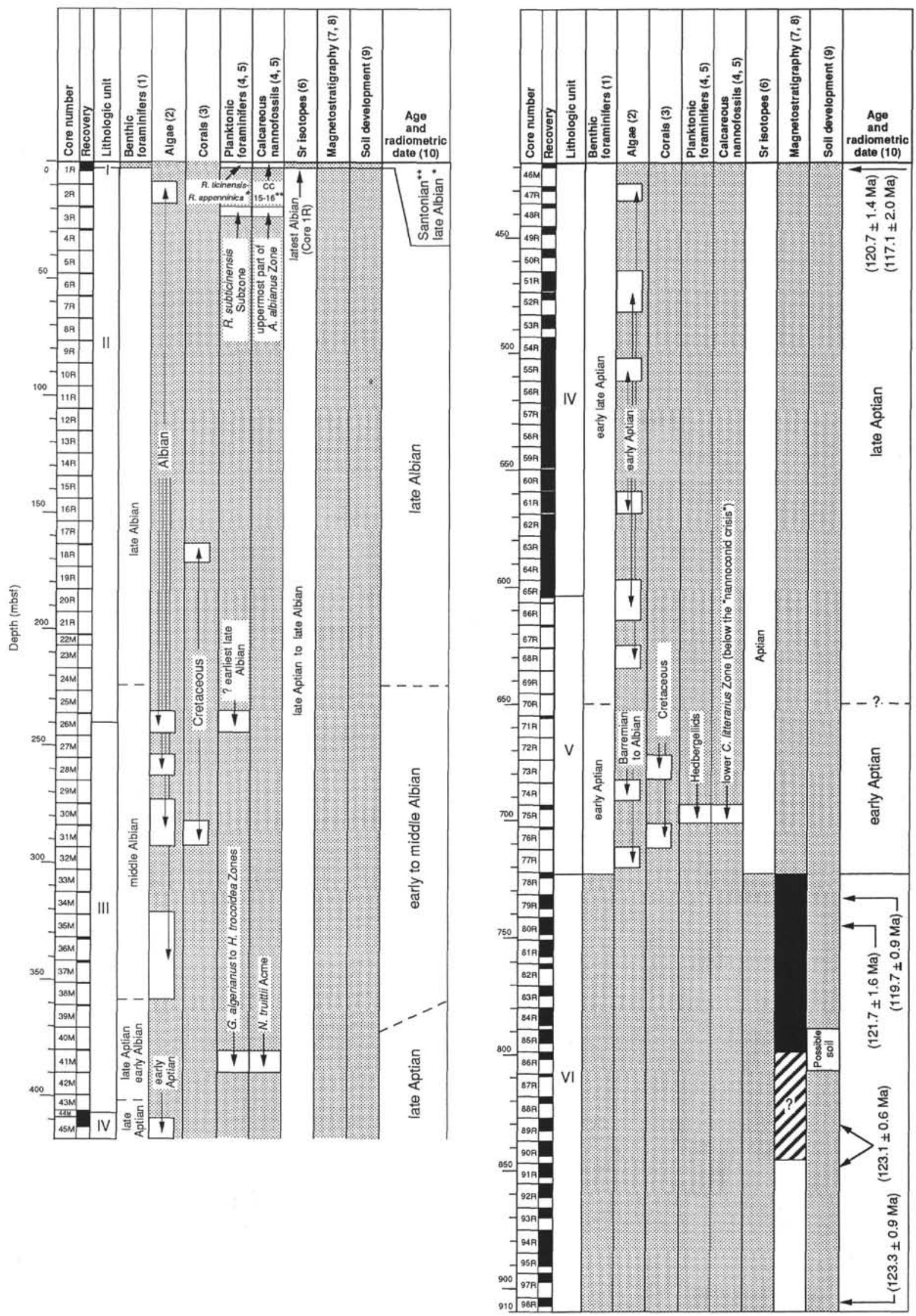

Figure 7. Stratigraphic synthesis of Hole 878A on MIT Guyot. Gray pattern corresponds to interval with no data. References are as follows: (1) Arnaud Vanneau and Premoli Silva (this volume); (2) Masse and Arnaud Vanneau (this volume); (3) Budd in Premoli Silva et al. (this volume); (4) Erba et al. (this volume); (5) Watkins et al. (this volume); (6) Wilson et al. (this volume); (7) Nakanishi and Gee (this volume); (8) Ito and Nogi (this volume); (9) Holmes (this volume); and (10) Pringle and Duncan (this volume). Asterisks identify the age of calcareous nannofossil (**) and planktonic foraminifer $(*)$ zones. 
are absent in the interval between Cores 144-878A-74R and $-42 \mathrm{M}$. Two samples from Core 144-878A-41M contain frequent nannofossils diagnostic of the Nannoconus truittii Acme of middle late Aptian age (Fig. 7). In the upper shallow-water limestone sequence, calcareous nannofossils occur in two samples (Cores 144-878A-3R and -2R, respectively), and assemblages are characterized by very low abundance and poor preservation. The early late Albian part of the Axopodorhabdus albianus Zone was identified (Erba et al., this volume).

A few layers belonging to both the upper and lower platform limestone yielded generally rare, poorly preserved planktonic foraminifers. The oldest assemblage in Core 144-878A-75R contains hedbergellids. A planktonic foraminifer assemblage occurs at the base of the upper carbonate platform sequence (Core 144-878A-41M); it is correlative of the Globigerinelloides algerianus to Hedbergella trocoidea Zones of middle late Aptian age. The poor preservation and scarcity of planktonic foraminifers in Core 144-878A-26M prevent any age assignment. The tentative identification of Rotalipora subticinensis in Core 144-878A-3R is diagnostic of the nominal subzone and suggests that the uppermost part of the shallow-water limestones is possibly dated as late Albian.

The occurrence of Planomalina praebuxtorfi, a short-ranging species that straddles the Rotalipora ticinensis/Rotalipora appenninica zonal boundary, in a manganese nodule atop the shallow-water carbonates (Watkins et al., this volume) indicates that the drowning of the platform occurred during a short interval before the end of the Albian. The oldest calcareous nannofossil assemblages preserved in manganese nodules are indicative of the Santonian CC15-CC16 Zones.

\section{TAKUYO-DAISAN GUYOT (SITE 879)}

Site 879 was drilled in $1501 \mathrm{~m}$ water depth on the southern margin of Takuyo-Daisan Guyot in the Seiko cluster of seamounts. Only one hole was cored to 226.95 mbsf. No pelagic cap was recovered at this site, where a carbonate platform immediately follows the volcanic substrate. Shallow-water limestones were recovered between 0 and 150.6 mbsf; argillaceous sandy limestone, calcareous claystone, volcanic conglomerate, calcareous sandstone, and rudstone from 150.6 to 169.7 mbsf; claystone with relict volcanic texture and conglomerates from 169.7 to $190.2 \mathrm{mbsf}$; and basalt breccia from 190.2 to $226.5 \mathrm{mbsf}$.

The radiometric ages of two samples from Cores 144-879-21R and $-22 \mathrm{R}$ were disregarded for dating the basalts at Site 879 (Unit III), and previously dredged material was considered for dating the volcanics on Takuyo-Daisan Guyot (Pringle and Duncan, this volume). A corrected age of $120.0 \pm 1.8 \mathrm{Ma}$ was derived from basalts of Dredge A5-37-3 from the flank of the guyot (Fig. 8). This age is consistent with that determined from basalts dredged from the nearby TakuyoDaini Seamount and is a good estimate of the age of basaltic volcanism in the Seiko seamount cluster (Pringle and Duncan, this volume).

Atop the basalts, a 40.2-m-thick clayey unit (top of Unit III and Unit II) may represent the deepest part of a weathering profile or alteration by groundwater (Holmes, this volume). The inception of marine sedimentation over the volcanic edifice at Takuyo-Daisan Guyot is well constrained by calcareous nannofossils and planktonic foraminifers in Cores 144-879A-18R, -17R, and -16R (Erba et al., this volume). The best nannofossil assemblages were observed at various levels in Core 144-879-17R and indicate the upper Aptian Rhagodiscus angustus Zone; the relative dominance of Nannoconus truittii in all these sample suggests that this core is correlative with the middle late Aptian N. truittii Acme. Similar, although depauperate, nannofloras occur in several samples from Core 144-879-18R. Most samples from Core 144-879A-16R lack calcareous nannofossils, but sparse specimens were recorded in a few layers. Again, although a precise age assignment is constrained by the paucity of nannofossils, the relative dominance of Nannoconus truittii suggests that the middle upper Aptian $N$. truittii Acme may extend to Core 144-879A-16R (Fig. 8) (Erba et al., this volume).
Planktonic foraminifer assemblages from the lower cores (144$879 \mathrm{~A}-18 \mathrm{R}$ to $-16 \mathrm{R}$ ), although of low abundance and diversity, appear homogeneous. The occurrence of forms attributed to Hedbergella trocoidea, Globigerinelloides ferreolensis, and possibly to Globigerinelloides algerianus and Globigerinelloides barri would indicate the Globigerinelloides algerianus to Hedbergella trocoidea Zones of early late Aptian age (Erba et al., this volume) (Fig. 8).

The stratigraphic resolution of the carbonate platform sequence at Site 879 (Unit I) is very poor because of the extremely low recovery. Biostratigraphy derives from benthic foraminifers (Arnaud Vanneau and Premoli Silva, this volume). Lithostratigraphic Subunits IE, ID, and IC, and the lowermost part of Subunit B (from Core 144-879-18R to $-15 R$ ) were attributed to the late Aptian and Subunit IA (Cores $144-879-6 R$ to $-1 R$ ) was dated as latest Albian. No data are available for most of Subunit IB (Cores 144-879-14R to -7R) because of the extremely low recovery.

Corals were found in Cores 144-879-10R and -2R, but are not age diagnostic (A.F. Budd in Premoli Silva et al., this volume). The paleoenvironmental implications of these coral findings are discussed by Premoli Silva et al. (this volume). Masse and Arnaud Vanneau (this volume) document the algal assemblages in Cores 144-879-16R, $-14 R,-3 R,-2 R$, and $-1 R$. A general Albian age is attributable to the carbonate platform section.

The Sr-isotope stratigraphy at Site 879 is based on a limited sample set as a result of the low recovery. No data are available for most of Subunit IB (Cores 144-879-14R to -7R). The lower part of the carbonate platform is late Aptian in age, and the upper portion is attributable to the late Albian (Wilson et al., this volume). The presence of Rotalipora ticinensis in Core 144-879A-2R, if correct, would indicate the late Albian Rotalipora ticinensis Zone (Erba et al., this volume) (Fig. 8).

The poor recovery in the middle part of the cored sequence at Site 879 prevents the identification of possible hiatuses. However, because the carbonate sequence at this site is only half the thickness of that deposited at Site 878 on MIT Guyot during the late Aptian to late Albian interval, accumulation of the shallow-water material at Site 879 was most probably affected by major breaks. The discrepancy between the benthic foraminifer biostratigraphic age (latest Albian) and the Sr-isotopic age (late but not latest Albian) for the top of the carbonate platform on Takuyo-Daisan Guyot, may be explained by reworking in a marginal marine setting. Possibly, Sr-isotopic measurements were conducted on late Albian shallow-water particles that were resedimented along the margin during the latest Albian.

The contact between the shallow-water limestones and the pelagic sediments was not recovered at Sites 879 and 880 , and therefore the age of drowning of Takuyo-Daisan Guyot remains unknown.

\section{CONCLUSIONS}

The timing of the formation of volcanic edifices, the deposition and demise of carbonate platforms, and subsequent pelagic sedimentation was reconstructed by correlations of bio-, magneto-, and isotope stratigraphies and radiometric dating of the sequences recovered at Sites 873 through 879 . Additional information derives from Site 869 drilled during Leg 143 and dredged material described in the literature. The geological history of the investigated guyots can be summarized as follows.

On Limalok Guyot, the subaerial weathering profile over the volcanics attests to a long period of exposure, with an estimated duration of as much as $3 \mathrm{~m}$.y., probably beginning in an upland area at least several tens of meters above sea level. The initial stage of inundation of the island occurred in the late Paleocene under relatively restricted conditions and was followed close to the Paleocene/ Eocene boundary by a thick sequence of shallow-water limestones that persisted through the early Eocene into the middle Eocene. The youngest platform carbonates were dated as early middle Eocene and drowning with establishment of open-marine conditions occurred in 


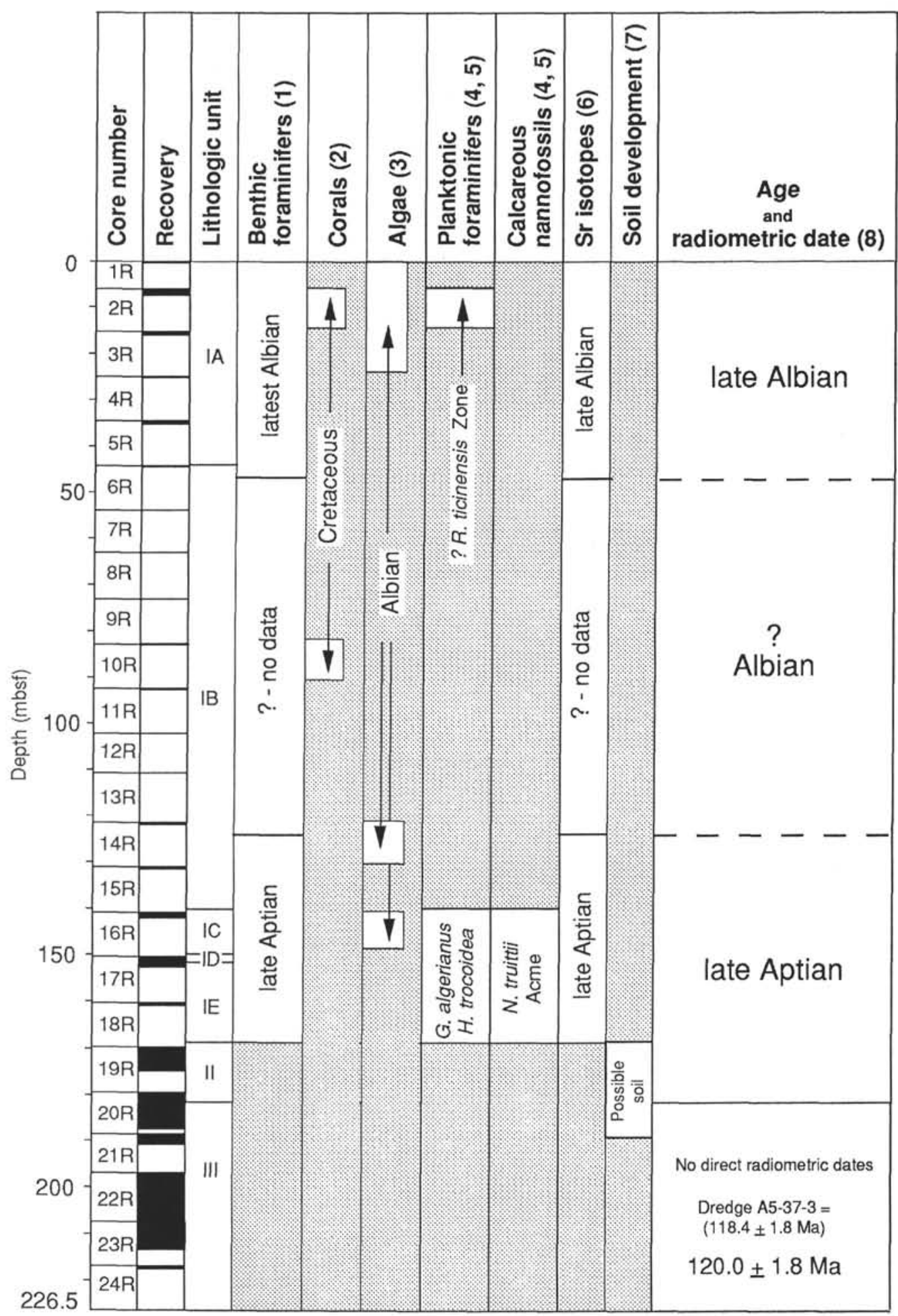

Figure 8. Stratigraphic synthesis of Hole 879A on Takuyo-Daisan Guyot. Gray pattern corresponds to interval with no data. References are as follows: (1) Arnaud Vanneau and Premoli Silva (this volume); (2) Budd in Premoli Silva et al. (this volume); (3) Masse and Arnaud Vanneau (this volume); (4) Erba et al. (this volume); (5) Watkins et al. (this volume); (6) Wilson et al. (this volume); (7) Holmes (this volume); and (8) Pringle and Duncan (this volume).

the middle Eocene, as recorded in the manganese crust atop the shallow-water sequence.

The volcanic pedestal on Lo-En Guyot gave an age of 114. $5 \pm 1.2$ $\mathrm{Ma}$. Although Lo-En Guyot is morphologically a classic guyot, drilling did not recover any platform sequence. Only few fragments of black claystones indicate a possible derivation from a weathered terrane, and the limestones recovered at this site suggest persistent pelagic deposition over the volcanic edifice near the center of the guyot since Albianearliest Cenomanian time. Material dredged along the southern flank of the guyot includes Albian shallow-water debris and pelagic sediment of latest Albian age. This findings suggest the presence of an $\mathrm{Al}$ bian carbonate platform subsequently drowned by latest Albian time. 
Drilling results from the summit of Wodejebato Guyot and on the archipelagic apron south of the feature, along with material dredged from the southern slope of the guyot, indicate that at least two episodes of volcanism are recorded in the area. The Cenomanian volcanism is documented by the thick volcaniclastic sequence at the apron site, whereas the occurrence of reworked nannofossils on the summit of Wodejebato Guyot confirms the presence of Cenomanian pelagic carbonates on the guyot. The age of the Cenomanian volcanics is $95.7 \pm 0.3 \mathrm{Ma}$. No shallow-water organisms of certain Cenomanian to Campanian age were recovered in the Wodejebato area, although rudist fragments dredged along the slope were dated as Albian or younger. If the Albian age is confirmed, then the Cenomanian episode disrupted an Albian carbonate platform but did not produce an island because the sediments interbedded with the volcanics, also Cenomanian in age, are pelagic in origin. Conversely, if the rudists are Cenomanian in age, then the Cenomanian produced a short-lived carbonate platform that was drowned by late Cenomanian time.

A younger volcanic episode, dated as early Campanian, is well documented on the summit of Wodejebato Guyot along the southern slope and at the apron site. The basalts are attributed to Chron 33R and gave a radiometric age of $84.4 \pm 1.1 \mathrm{Ma}$. After a period of weathering and pedogenesis, marine sedimentation started in the late Campanian under restricted conditions and was followed by the establishment of a late Campanian to Maastrichtian carbonate platform. The youngest shallow-water carbonates are late Maastrichtian in age and only slightly older than the late Maastrichtian drowning of Wodejebato Guyot, as documented by pelagic limestones infilling the top of the platform.

The age of the volcanic pedestal on MIT Guyot ranges from 124.5 to $121.3 \mathrm{Ma}$. The bottom $60 \mathrm{~m}$ of basalts were identified as Chron $\mathrm{M} 1 \mathrm{r}$ of late Barremian age. Atop the volcanics, a thin clayey interval may represent the very deep parts of a soil profile or alteration by groundwaters. Shallow-water deposition was established during the early Aptian and was abruptly interrupted by a volcanic episode in the late early Aptian. This volcanism was followed by deposition of a younger carbonate platform in the late Aptian to Albian. Although benthic foraminifers indicate that the youngest carbonate platform is late Albian in age, Sr-isotope stratigraphy suggests a latest Albian age for the top of the platform. Manganese crusts and nodules were found atop the shallow-water platforms and within the pelagic cap on MIT Guyot. The oldest pelagic sediment indicates that the drowning of the platform occurred in a short interval before the end of the Albian.

The volcanic pedestal on Takuyo-Daisan Guyot was dated using the age of $120.0 \pm 1.8 \mathrm{Ma}$ derived from Dredge A5-37-3 from the flank of the guyot. Atop the basalts, a clayey unit may represent the deepest part of a weathering profile or alteration by groundwater. Carbonate platform deposition is represented by shallow-water limestones of late Aptian to Albian age. The initial flooding of the volcanic edifice at Takuyo-Daisan Guyot is constrained to the middle late Aptian. The top of the carbonate platform was attributed to the latest Albian. The contact between shallow-water limestones and pelagic sediments was not recovered, hence the age of drowning of the Takuyo-Daisan Guyot remains unknown.

\section{ACKNOWLEDGMENTS}

ODP is greatly acknowledged for inviting us to participate on legs 144 and 143 . This synthesis benefitted of discussion and support by both legs 143 and 144 scientific parties: we really enjoyed the cooperation with such a diverse group of friends and colleagues. The authors are indebted to Esmeralda Caus for her advice on distribution of Upper Cretaceous large benthic foraminifers. Hugh Jenkyns and Felix Gradstein are warmly thanked for suggestions and review of the manuscript. The research was supported by Italian CNR funds to EE and IPS.

\section{REFERENCES ${ }^{*}$}

Cecca, F., Pallini, G., Erba, E., Premoli Silva, I., and Coccioni, R., 1994. Hauterivian-Barremian chronostratigraphy based on ammonites, nanno- fossils, planktonic foraminifera and magnetic chrons from the Mediterranean domain. Cretaceous Res., 15:457-467.

Coccioni, R., and Premoli Silva, I., 1994. Planktonic foraminifera from the Lower Cretaceous of Rio Argos sections (southern Spain) and biostratigraphic implications. Cretaceous Res., 15:645-687.

Erba, E., 1994. Nannofossils and superplumes: the early Aptian "nannoconid crisis." Paleoceanography, 9:483-501.

Gradstein, F.M., Agterberg, F.P., Ogg, J.G., Hardenbol, J., van Veen, P., Thierry, J., and Huang, Z., 1994. A Mesozoic time scale. J. Geophys. Res., 99:24051-24074.

Jenkyns, H.C., Mutterlose, J., and Sliter, W.V., 1995. Upper Cretaceous carbon- and oxygen-isotope stratigraphy of deep-water sediments from the north-central Pacific (Site 869, Flank of Pikinni-Wodejebato, Marshall Islands). In Winterer, E.L., Sager, W.W., Firth, J.V., and Sinton, J.M. (Eds.), Proc. ODP, Sci. Results, 143: College Station, TX (Ocean Drilling Program), 105-108.

Jones, C.E., 1992. The strontium isotopic composition of Jurassic and Early Cretaceous seawater [Ph.D. dissert.]. Oxford Univ.

Krijnen, J.P., MacGillavry, H.J., and Van Dommelen, H., 1993. Review of upper Cretaceous orbitoidal larger foraminifera from Jamaica, West Indies, and their connection with rudist assemblages. Mem.-Geol. Soc. Am., 182:29-63.

Lincoln, J.M., Pringle, M.S., and Premoli-Silva, I., 1993. Early and Late Cretaceous volcanism and reef-building in the Marshall Islands. In Pringle, M.S., Sager, W.W., Sliter, W.V., and Stein, S. (Eds.), The Mesozoic Pacific: Geology, Tectonics, and Volcanism. Geophys. Monogr., Am. Geophys. Union, 77:279-305.

McArthur, J.M., 1994. Recent trends in strontium isotope stratigraphy. Terra Nova, 6:331-358.

McArthur, J.M., Kennedy, W.J., Gale, A.S., Thirlwall, M.F., Chen, M., and Hancock, J.M., 1992. Strontium isotope stratigraphy in the Late Cretaceous intercontinental correlation of the Campanian/Maastrichtian boundary. Terra Nova, 4:385-393.

McArthur, J.M., Thirlwall, M.F., Chen, M., Gale, A.S., and Kennedy, W.J., 1993. Strontium isotope stratigraphy in the Late Cretaceous: numerical calibration of the $\mathrm{Sr}$ isotope curve and intercontinental correlation for the Campanian. Paleoceanography, 8:859-873.

Neumann, M., 1993. Le genre Orbitoides. II. Revision des différentes espèces. Rev. Micropaleontol., 36:301-353.

Obradovich, J.D., 1993. A Cretaceous time scale. In Caldwell, W.G.E., and Kauffman, E.G. (Eds.), Evolution of the Western Interior Basin. Spec. Pap. Geol. Assoc. Can., 39:379-396.

Premoli Silva, I., Haggerty, J., Rack, F., et al., 1993. Proc. ODP, Init. Repts., 144: College Station, TX (Ocean Drilling Program).

Premoli Silva, I., and Sliter, W.V., 1994. Cretaceous planktonic foraminiferal biostratigraphy and evolutionary trends from the Bottaccione Section, Gubbio, Italy. Palaeontogr. Ital., 81:2-90.

Sager, W.W., Tarduno, J.A., and MacLeod, C.J., 1995. Paleomagnetism of Cretaceous sediments, Hole 869B, Marshall Islands: magnetic polarity, paleolatitude, and a paleomagnetic pole. In Winterer, E.L., Sager, W.W., Firth, J.V., and Sinton, J.M. (Eds.), Proc. ODP, Sci. Results, 143: College Station, TX (Ocean Drilling Project), 405-418.

Sager, W.W., Winterer, E.L., Firth, J.V., et al., 1993. Proc. ODP, Init. Repts., 143: College Station, TX (Ocean Drilling Program).

Schroeder, R., and Neumann, M. (Eds.), 1985. Les Grandes Foraminiferes $d u$ Crétacé Moyen de la Région Méditerranéenne. Geobios, Spec. Mem., 7.

Shipboard Scientific Party, 1993. Insight on the formation of Pacific guyots from ODP Leg 144. Eos, 74:358-366.

Sliter, W.V., 1995. Cretaceous planktonic foraminifers from Sites 865,866 , and 869: a synthesis of Cretaceous pelagic sedimentation in the central Pacific Ocean Basin. In Winterer, E.L., Sager, W.W., Firth, J.V., and Sinton, J.M. (Eds.), Proc. ODP, Sci. Results, 143: College Station, TX (Ocean Drilling Program), 15-30.

van Gorsel, J.J., 1978. Late Cretaceous orbitoidal foraminifera. In Hedley, R.H., and Adams, C.G. (Eds.), Foraminifera (Vol. 3): London (Academic Press), 1-120.

\footnotetext{
Abbreviations for names of organizations and publications in ODP reference lists follow the style given in Chemical Abstracts Service Source Index (published by American Chemical Society).
}

Date of initial receipt: 2 August 1994

Date of acceptance: 1 November 1994

Ms 144SR-076 